\title{
Technical mapping of solar photovoltaic for the Coal City of India
}

\author{
Suprava Chakraborty ${ }^{*}$ and Pradip Kumar Sadhu
}

\begin{abstract}
Performance of nine commercial solar photovoltaic (PV) panels from different manufacturers with combination of different manufacturing materials and technologies are studied under the environmental conditions of the Coal City of India. The results give an indication of the comparative performance of different PV technologies under the aforesaid location's environmental condition which helps to choose the best suitable PV technology for the Coal City of India. This procedure is commonly known as technical mapping of solar PV. Performance of PV panels made of Maxeon Cell Technology, heterojunction with intrinsic thin layer (HIT), mono-crystalline silicon (Mono C-Si), poly-crystalline silicon (Poly C-Si), Micromorph, SCHOTT, amorphous silicon (a-Si), copper indium gallium selenide (CIGS) and cadmium telluride (CdTe) technologies is analysed. Meteorological and PV panel parameters required for the study are collected from National Aeronautics and Space Administration (NASA) renewable energy resource website (Surface Meteorology and Solar Energy) and the data sheets of commercial PV panel manufacturers, respectively. The outcome of this study concludes that modules made of amorphous silicon technology perform better under the typical temperature variant and dry environmental condition of the Coal City of India. The same PV technology is also best suited considering life cycle assessment and global warming impact point of view for the concerned site.
\end{abstract}

Keywords: Coal City of India; Environmental condition; PV technology; Technical mapping; Life cycle assessment; Global warming impact

\section{Background}

Most of the countries in the world are facing serious shortages of energy due to inadequate reserves of non-renewable sources of energy. In India, the cost of electricity has risen $20 \%$ since the year 2009. In the twenty-firstcentury, renewable energy resources are getting priority due to the diminution of fossil fuels and gradual emerging consciousness about the environmental degradation (Chen et al. 2010). Solar energy is one of the most important fields of renewable energy. Fiorenza et al. studied the techno-economic prospect of a Salt Gradient Solar Pond (Fiorenza et al. 2006). Grid interactive solar PV systems are gradually becoming a more feasible alternative for electricity generation due to technology improvement and drop in component prices in comparison with the escalating cost of fossil fuels (Nanda and Raturi 2013). It is a budding area of research to evaluate the accurate performance of PV system

\footnotetext{
* Correspondence: suprava1008@gmail.com

Department of Electrical Engineering, Indian School of Mines, Dhanbad,
} Jharkhand, India826004 in practical conditions as the outdoor environment differs from the standard test conditions (STC) at which PV panels are rated.

Technical mapping of solar PV for a particular location is a very important and growing field of research worldwide. Pavlovic et al. compared the total electricity produced from mono-crystalline silicon, cadmium telluride (CdTe) and CIS solar panels of $1 \mathrm{~kW}$ capacity PV power plant for 1 year in the climatic conditions of the Republic of Srpska (Pavlovic et al. 2013). The performance of four different solar modules made of mono-crystalline silicon, polycrystalline silicon, amorphous silicon and $\mathrm{CdS} / \mathrm{CdTe}$ technologies under the environmental conditions of Mexico City was compared and results showed a better performance for amorphous silicon technology (Santana-Rodŕiguez et al. 2013). Amorphous silicon performs well under Malaysia's tropical hot and humid climate, due to favorable, constant, high solar radiation in Malaysia and predominant diffuse nature of solar radiation (Daghigh et al. 2011). Performance losses in grid-connected photovoltaic systems

\section{Springer}

(c) 2015 Chakraborty and Sadhu. This is an Open Access article distributed under the terms of the Creative Commons Attribution License (http://creativecommons.org/licenses/by/4.0), which permits unrestricted use, distribution, and reproduction in any medium, provided the original work is properly credited. 
were studied and results showed that the temperature is the main source of loss in high irradiance countries predominately for mono and multi-crystalline technologies (Makrides et al. 2010). PV modules with high-temperature coefficient are advantageous for use in the Gobi desert area (Adiyabat et al. 2006). Relative humidity and solar flux have a negligible effect on the output voltage of the PV module (Swift 2013).

The behaviour of a particular solar module depends not only on the material and technology used but also on the environmental conditions at which it is operating. Environmental conditions have a direct influence on the behaviour of the electrical parameters of PV modules manufactured through unlike technologies. For these reasons, technical mapping of solar PV for a particular location is needed. Technical mapping of solar PV for the Coal City of India is the focus of this paper. Air pollution is a problem in Dhanbad as it is the coal capital of India. So the behaviour of the electrical parameters for different PV technologies under the specific environment of Dhanbad is studied in this paper to promote Solar PV. A map of Dhanbad city is shown in Fig. 1. It is situated in the state of Jharkhand, India, and lies between $23^{\circ} 37^{\prime} 3^{\prime \prime} \mathrm{N}$ and $24^{\circ} 4^{\prime} \mathrm{N}$ latitude and between 86 $6^{\prime} 30^{\prime \prime} \mathrm{E}$ and 86 $50^{\prime} \mathrm{E}$ longitude. Dhanbad is bounded by Giridih, Bokaro, Dumka of Jharkhand and Purulia district of West Bengal.

Climatic condition of India varies enormously due to its position in the world map. The main objective of this paper is to find out which PV technology shows the best performance under the specific environmental condition of Dhanbad (Coal City of India). In a laboratory scale, there are many new PV technologies available such as organic solar cell and dye-sensitized solar cells, but they are not used commercially for PV power plant. Hence, nine commercial PV technologies from reputed manufacturers are considered which are extensively tested and widely used for commercial PV power plant projects.The meteorological parameters of the concerned site, required for technical mapping of solar PV are extensively studied. To judge the economical feasibility and environmental

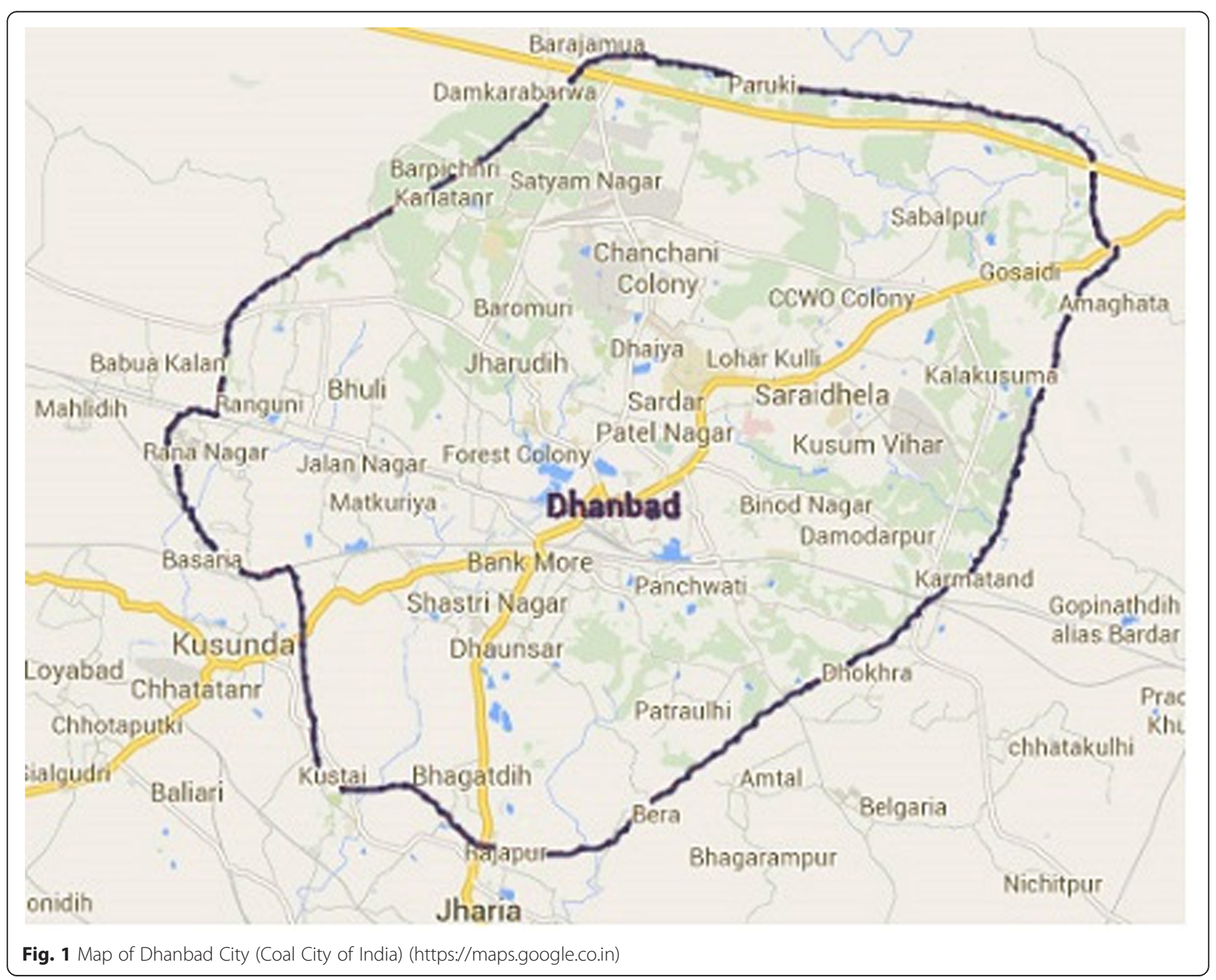


impact of the proposed project, life cycle assessment (LCA) and global warming impact study for the selected PV technologies are also performed. This paper will help the PV project developers, planning commission and engineers to choose best suitable PV technology for the Coal City of India, not only considering the technical performance but also from the economic and environmental point of view.

\section{Different types of solar PV projects in India}

The installed grid interactive solar PV power capacity of India is $3.744 \mathrm{GW}$ by the end of March 2015, which is $42.25 \%$ higher from the previous year (http:// www.mnre.gov.in/solar-mission/jnnsm/introduction-2/). In India, $50 \%$ of the total installed capacity of solar PV power is contributed by the state Gujarat. Asia's largest solar park has commissioned by Gujarat at Charanka village with a capacity of $500 \mathrm{MW}$. After completion of 4 GW Ultra Mega Green Solar Power Project (UMPP) near Sambhar Lake in Rajasthan, it will be the world's largest solar power plant (http://www.mnre.gov.in/solarmission/jnnsm/introduction-2/). A 10-MW solar PV plant based on amorphous silicon (a-Si) technology in Osmanabad, Maharashtra, generates approximately $18 \mathrm{GWh} / \mathrm{MW}$ which is the maximum generation in Maharashtra among the solar PV plants (http://www.relyonsolar.com/). Under the scheme of Jawaharlal Nehru National Solar Mission (JNNSM), numbers of solar PV plants are already installed in India and many others are going to be installed to fulfil the target of JNNSM. For successful execution of JNNSM, NTPC Vidyut Vyapar Nigam Ltd (NVVN) (http://nvvn.co.in/) has given the responsibility to prepare the guidelines for selection of developers for commissioning grid-connected solar power projects in India. Most of the solar PV plants installed in India are based on a-Si technology. Only some of them are based on other PV technologies such as 5-MW solar PV plant installed by Pokaran Solaire Energy Private Limited in Jodhpur considered monocrystalline silicon (Mono C-Si) technology PV modules for their project and 10-MW solar PV plant installed by Sai Mathili Power Company Private Limited in Bikaner district of Rajasthan installed copper indium gallium selenide (CIGS) technology for their PV plant. Solar PV generation costs have reduced from around Rs.18/kWh to about Rs.7/kWh in the last 3 years, whereas cost of coal-based thermal power is around Rs.4.5/kWh and it is escalating with time (http://www.mnre.gov.in/solar-mission/jnnsm/introduction-2/). Continuous cost reduction of PV will make it compatible with fossil fuel in a few years (Muneer et al. 2005). Solar power is the strength of Indian energy economy without deteriorating environmental condition and enhancing the economical growth.

\section{Methods}

Mathematical equations used for technical mapping of solar PV are discussed in the consecutive section. Related meteorological parameters of Dhanbad (Coal City of India) are collected from National Aeronautics and Space Administration (NASA) renewable energy resource website (Surface Meteorology and Solar Energy) (https://eosweb.larc.nasa.gov/sse). The investigation is performed based on a conventional PV power plant designing method and information obtained from reputed PV module manufacturer datasheets. Life cycle analysis and global warming impact study of the nine selected commercial PV technologies are also performed using the secondary data which is collected from PV power plant developers. The mathematical equations required for technical mapping study, LCA and global warming impact study are described in the List of saints section. Stepwise methodology of the study is presented in Fig. 2. Capacity of the PV plant is considered $1 \mathrm{MW}$ for convenience.

\section{Mathematical equations required for technical mapping, LCA, global warming impact}

Mathematical equations used for technical mapping of solar PV are discussed in the consecutive section.

\section{Temperature effect on nominal rated performance of PV array}

The daily output of a solar PV array depends on solar radiation and PV operating temperature. Rise in the PV operating temperature reduces array peak energy output and efficiency. PV panel performance is generally rated in standard test condition (STC), i.e. considering irradiance of $1000 \mathrm{~W} / \mathrm{m}^{2}$, solar spectrum of AM $1.5 \mathrm{G}$ and temperature at $25{ }^{\circ} \mathrm{C}$. But actual operating environmental parameters of PV plants differ from STC parameters. Therefore, to judge the actual PV panel performance, the panel should be tested in specified environmental condition of the plant location. PV operating temperature can be calculated considering the ambient temperature at a given location, nominal operating cell temperature (NOCT) of the particular technology and incident solar intensity on PV array (Ross 1976; Skoplaki and Palyvos 2009; Garcia and Balenzategui 2004; Malik and Damit 2003). Consequence of including the effects of PV operating temperature in the PV electrical energy output is presented by Eqs. 1 and 2, respectively.

\section{Panel operating temperature}

$$
T_{\mathrm{PO}}=T_{\mathrm{AMB}}+\frac{(\mathrm{NOCT}-20)}{800} \times G
$$

$T_{\mathrm{PO}}$ is the panel operating temperature in ${ }^{\circ} \mathrm{C}$.

$T_{\mathrm{AMB}}$ is the ambient temperature in ${ }^{\circ} \mathrm{C}$. 


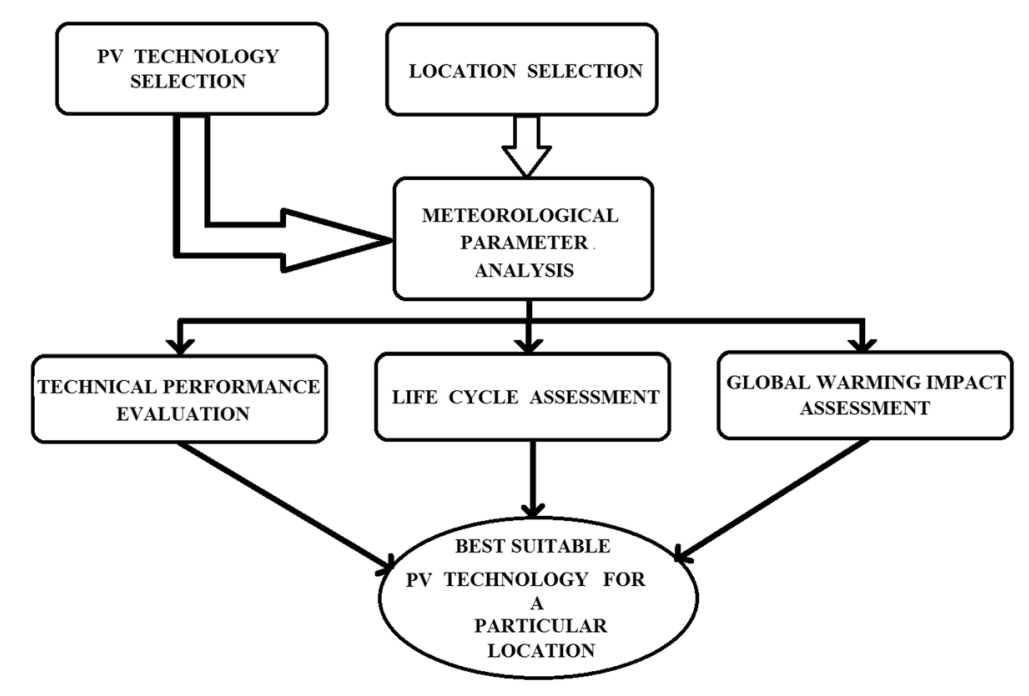

Fig. 2 Stepwise methodology

NOCT is the nominal operating cell temperature.

$G$ is the irradiance in $\mathrm{W} / \mathrm{m}^{2}$.

Considering only temperature correction and neglecting irradiance correction, Eq. 1 becomes

$$
T_{\mathrm{PO}}=T_{\mathrm{AMB}}+(\mathrm{NOCT}-20)
$$

So from Eq. 2, panel operating temperature of a PV technology can be determined if NOCT of that particular technology and ambient temperature of the concerned site are known.

Reduction in power output from PV panel due to variation of panel temperature from STC

Reduction in panel output due to temperature correction

$$
\mathrm{RP}_{\mathrm{TC}}=\left(T_{\mathrm{PO}}-T_{\mathrm{STC}}\right) \times \gamma
$$

$\mathrm{RP}_{\mathrm{TC}}$ is the reduction in power output due to temperature correction in \%.

$\gamma$ is the temperature coefficient of power for PV panel in $\% /{ }^{\circ} \mathrm{C}$.

$T_{\mathrm{STC}}$ is the temperature of the PV module at STC in ${ }^{\circ} \mathrm{C}$ (i.e. $25^{\circ} \mathrm{C}$ ).

\section{Panel output after temperature correction}

$$
P_{\mathrm{TC}}=P_{\mathrm{MAX}}\left(1-\mathrm{RP}_{\mathrm{TC}}\right)
$$

$P_{\mathrm{TC}}$ is the panel output after temperature correction.

$P_{\text {MAX }}$ is the power output at STC.
Equivalent full sunshine hours in latitude angle tilted surface

Equivalent hours of full sunshine are defined by the number of hours of incident radiation at a place, if intensity of radiation is kept constant at its peak value of $1 \mathrm{~kW} / \mathrm{m}^{2}$. Suppose, insolation on a latitude angle tilted unit area surface is expressed by $I_{\mathrm{T}} \mathrm{kWh} / \mathrm{m}^{2} /$ day, then this can further be expressed as constant peak value of solar radiation of $1 \mathrm{~kW} / \mathrm{m}^{2}$ incident on receiving surface for $I_{\mathrm{T}}$ hours, then $h_{\mathrm{EFSLAT}}$ will be equal to $I_{\mathrm{T}}$ hours/day. The expression is given by Eq. 5 .

$$
h_{\mathrm{EFSLAT}}=\frac{I_{\mathrm{T}}}{1 \mathrm{~kW} / \mathrm{m}^{2}}
$$

$h_{\text {EFSLAT }}$ is the equivalent full sunshine hours in latitude angle tilted surface.

$I_{\mathrm{T}}$ is the insolation on tilted surface (for Dhanbad fixed tilt is taken as $23^{\circ}$ ) in $\mathrm{kWh} / \mathrm{m}^{2} /$ day.

\section{Energy output from the PV panel}

$$
\xi_{\text {Panel }}=P_{\mathrm{TC}} \times h_{\mathrm{EFSLAT}}(1-\mathrm{DF})
$$

$\xi_{\text {Panel }}$ is the energy output from PV panel.

DF is the dust factor in \%.

\section{Energy output from inverter}

$$
\operatorname{Inv}_{O / P}=\xi_{\text {Panel }} \times \eta_{\text {inv }}
$$

$\operatorname{Inv}_{O / P}$ is the energy output from inverter.

$\eta_{\text {inv }}$ is the inverter efficiency in \%.

\section{Performance ratio}

The performance ratio (PR) is a system performance index that indicates the overall effect of losses on the 
array's rated output due to array temperature, incomplete utilization of the irradiation and system component inefficiencies or failures (IEC 61724). Performance ratios are usually reported on a monthly or yearly basis. A PR value calculated for smaller intervals, such as weekly or daily is useful to identify the occurrences of component failures.

$$
\mathrm{PR}=\frac{\mathrm{Inv}_{O / P}}{A_{a} \times I_{T} \times \eta_{\text {Panel }}} \times 100
$$

$\mathrm{PR}$ is the performance ratio in \%.

$A_{a}$ is the active area of panel.

$\eta_{\text {Panel }}$ is the solar panel efficiency in \%.

\section{Energy yield factor}

Energy yield factor (YF) of the PV system defined as the portion of the daily net energy output of the entire PV plant which is supplied by the array per $\mathrm{kW}$ of installed PV array.

$$
\mathrm{YF}=\frac{\operatorname{Inv}_{O / P}}{P_{\mathrm{MAX}}}
$$

YF is the yield factor.

\section{Life cycle assessment}

Life cycle assessment (LCA) of the PV plants indicates economically feasible for the proposed project and also determines its payback period. LCA uses two techniques, net present value (NPV) and payback period. Equations required for LCA are discussed sequentially.

\section{Capital cost}

Capital cost,

$$
\begin{aligned}
C_{\mathrm{C}}= & C_{\mathrm{PVM}}+C_{\mathrm{L}}+C_{\mathrm{CG}}+C_{\mathrm{MS}}+C_{\mathrm{PCU}}+C_{\mathrm{CT}} \\
& +C_{\mathrm{PP}}
\end{aligned}
$$

$C_{\mathrm{C}}$ is the capital cost of PV plant, $C_{\mathrm{PVM}}$ is the cost of the PV module, $C_{\mathrm{L}}$ is the land cost, $C_{\mathrm{CG}}$ is the cost of civil and general works, $C_{\mathrm{MS}}$ is the cost of mounting structures, $C_{\mathrm{PCU}}$ is the cost of the Power Conditioning Unit, $C_{\mathrm{CT}}$ is the evacuation cost up to inter-connection point (cables and transformer), and $C_{\mathrm{PP}}$ is the preliminary and pre-operative expenses.

\section{Operation and maintenance cost}

$$
\mathrm{NPV}_{\mathrm{OMC}}=\frac{C_{\mathrm{AOM}}}{(d-g)}\left[1-\left(\frac{1+g}{1+d}\right)^{n}\right]
$$

$\mathrm{NPV}_{\mathrm{OMC}}$ is the net present value of operation and maintenance cost, $C_{\mathrm{AOM}}$ is the annual operation and maintenance cost, $d$ is the discount rate (\%), $g$ is the escalation in operation and maintenance cost (\%), and $n$ is the lifetime of the project (years).

\section{Total outflow of money}

$$
\mathrm{TO}_{\mathrm{M}}=C_{\mathrm{C}}+\mathrm{NPV}_{\mathrm{OMC}}
$$

$\mathrm{TO}_{\mathrm{M}}$ is the total outflow of money.

\section{Saving from electricity generated by the PV plant}

$$
\mathrm{AS}_{\mathrm{EG}}=\mathrm{IC}_{\mathrm{PV}} \times \mathrm{YF} \times N \times T_{\mathrm{E}}
$$

$\mathrm{AS}_{\mathrm{EG}}$ is the annual saving from electricity generated by the PV plant, $\mathrm{IC}_{\mathrm{PV}}$ is the installed Capacity of $\mathrm{PV}$ plant, $Y F$ is the yield factor, $N$ is the number of working days in the year, and $T_{E}$ is the tariff of electricity.

$$
\mathrm{NPV}_{\mathrm{SEG}}=\frac{\mathrm{AS}_{\mathrm{EG}}}{(d-g)}\left[1-\left(\frac{1+i}{1+d}\right)^{n}\right]
$$

$\mathrm{NPV}_{\mathrm{SEG}}$ is the net present value of lifetime saving from electricity generated by the PV plant, $d$ is the discount rate (\%), $i$ is the inflation rate of electricity tariff (\%), $n$ lifetime of the project (years).

\section{Total inflow of money}

$$
\mathrm{TI}_{\mathrm{M}}=\mathrm{NPV}_{\mathrm{SEG}}+\mathrm{NPV}_{\mathrm{SV}}
$$

$\mathrm{TI}_{\mathrm{M}}$ is the total inflow of money, $\mathrm{NPV}_{\mathrm{SV}}$ is the net present value of salvage value.

$$
\mathrm{NPV}_{\mathrm{SV}}=\frac{\mathrm{SV}}{(1+d)^{n}}
$$

SV is the salvage value.

\section{Net present value of project}

$$
\mathrm{NPV}_{\mathrm{P}}=\mathrm{TI}_{\mathrm{M}}-\mathrm{TO}_{\mathrm{M}}
$$

$\mathrm{NPV}_{\mathrm{P}}$ is the net present value of PV power plant.

\section{Payback period}

$$
\mathrm{PBP}=\frac{\mathrm{TO}_{\mathrm{M}}}{\mathrm{AS}_{\mathrm{EG}}}
$$

PBP is the payback period in years.

\section{Global warming impact}

$$
\mathrm{AER}_{\mathrm{GHG}}=\mathrm{IC}_{\mathrm{P}} \times Y F \times N \times \mathrm{ECP}_{\mathrm{GHG}}
$$

$\mathrm{AER}_{\mathrm{GHG}}$ is the annual GHG emission reduction from PV power plant.

$\mathrm{ECP}_{\mathrm{GHG}}$ is the GHG emission from coal-based power plant $/ \mathrm{kWh}$. 


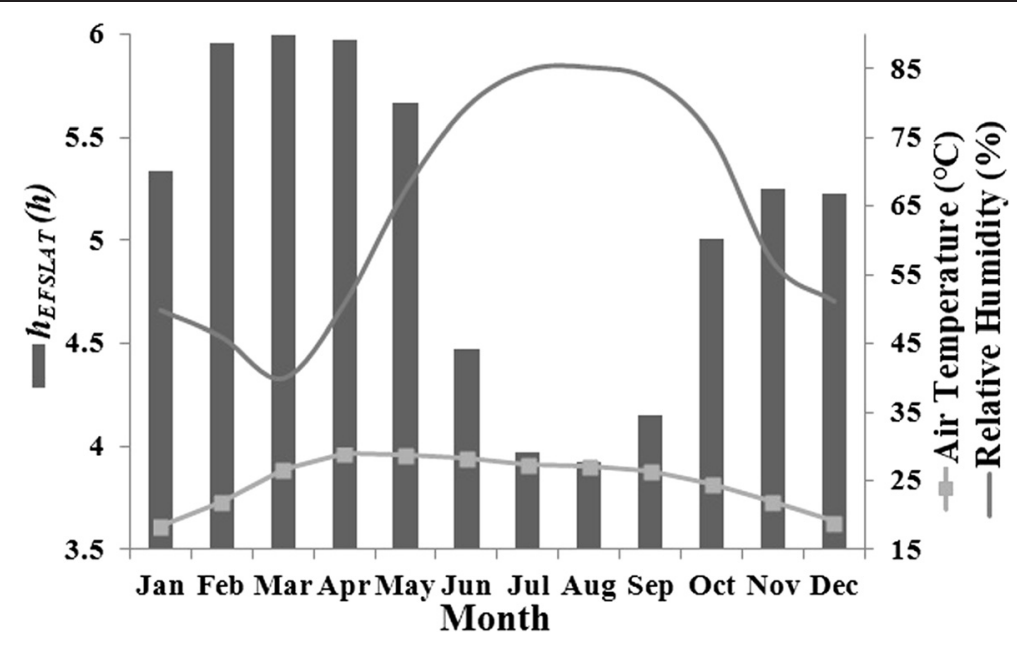

Fig. 3 Meteorological parameters of Dhanbad

\section{Climatic characteristics for the Coal City of India} Meteorological parameters of the Coal City of India (Dhanbad) are collected from National Aeronautics and Space Administration (NASA) renewable energy resource website (Surface Meteorology and Solar Energy) (https://eosweb.larc.nasa.gov/sse/). The climate of Dhanbad district is characterized by general dryness. Panels are considered to be mounted with a fixed tilt of $23^{\circ}$ to maximize annual energy production. Fixed PV solar plant denotes that a plant with solar modules mounted on fixed metal support structure under optimal angle in relation to the horizontal surface and all are oriented towards equator. Fixed tilt systems are lighter in weight, are less expensive and produce less energy per installed kilowatt on an annual basis than a tracking system. In addition, the use of a tracking system for small solar panels is not recommended due to high-energy losses in the driving systems. The power consumption by a tracking device is $2-3 \%$ of the increased energy from the PV system (Mousazadeh et al. 2009). The average solar potential on a tilted surface facing towards the equator is $5.08 \mathrm{kWh} / \mathrm{m}^{2} /$ day, which is representative of the Coal City's solar potential. Ambient temperature varies from 18.3 to $28.9{ }^{\circ} \mathrm{C}$ in the concerned site with an annual average of $24.9{ }^{\circ} \mathrm{C}$. Detail meteorological parameters used for calculation are shown in Fig. 3. The scale for the equivalent hours of full sunshine is shown on the left-hand side, and the scale for the remaining parameters is indicated in the right-hand side of the figure.

Based on international standards that consider an average solar radiation density incident on Earth's surface equivalent to $1 \mathrm{~kW} / \mathrm{m}^{2}$ (solar irradiance), we calculated the average of daily equivalent hours of full sunshine $\left(h_{\mathrm{EFSLAT}}\right)$ of the Coal City of India. Figure 3 shows the monthly average $h_{\text {EFSLAT }}$, from which we have calculated an annual average of $5.08 \mathrm{~h} /$ day. Again, from this figure, it is seen that average $h_{\text {EFSLAT }}$ is greater than $5.8 \mathrm{~h}$ /day in the months of February, March and April. The same is below $4 \mathrm{~h}$ /day in the month of July and August. Air temperature varies from 18.3 to $28.9{ }^{\circ} \mathrm{C}$ in the concerned site with an annual average of $24.9{ }^{\circ} \mathrm{C}$. Relative humidity $(\mathrm{RH})$ of the Coal City of India varies

Table 1 Technical specifications of selected PV panels

\begin{tabular}{|c|c|c|c|c|c|}
\hline $\bar{M}$ & MT & Tech & $P_{\max }$ & $T_{c}$ & $\overline{\mathrm{NOCT}}$ \\
\hline Sun Power & SPR-435NE-WHT-D & Maxeon Cell Technology & 435 & 0.38 & 45 \\
\hline SANYO Electric Co., Ltd. & HIT-H250E01 & HIT & 250 & 0.3 & 46 \\
\hline Helios Solar & Helios Solar 9T6-420 & Mono-crystalline & 420 & 0.41 & 45 \\
\hline Conergy & PE-300 & Poly-crystalline & 300 & 0.43 & 47 \\
\hline Silevo Triex & Silev o Triex -U300 Black & $\begin{array}{l}\text { Micromorph (Mono C-Si and } \\
\text { amorphous silicon hybrid) }\end{array}$ & 300 & 0.27 & 46 \\
\hline SCHOTT Solar & SCHOTT PROTECT'M ASI CLIME Series 116 & SCHOTT & 116 & 0.2 & 49 \\
\hline Sungen International Limited & SG-HN105-GG & $\mathrm{a}-\mathrm{Si}$ & 100 & 0.268 & 40.28 \\
\hline Stion & STO-150 & CIGS & 150 & 0.26 & 45.6 \\
\hline First Solar & FS-385 & $\mathrm{CdTe}$ & 85 & 0.25 & 45 \\
\hline
\end{tabular}


from 39.90 to $85.30 \%$ as shown in Fig. 3. Maximum and minimum $\mathrm{RH}$ are observed in the months of August and March, respectively. Only in the months of July, August and September RH is greater than $80 \%$. Annual average humidity of the Coal City is $64.18 \%$ which characterized its climate as dry. The entry of moisture into photovoltaic (PV) modules causes degradation which leads to rise in failure rates (Gwandu and Creasey 1995; Cher Ming Tan, Boon Khai Eric Chen and Kok Peng Toh 2010; Kempe 2006), particularly in hot and humid climatic condition (Kempe 2006). The humidity level of the Coal City is inadequate to endanger the performance of PV module. Lower relative humidity is observed in the Coal City as it is situated far away from the sea coast. Dust is another major parameter affecting the output of PV module (Mani and Pillai 2010; Garg 1974). It is reported that the presence of a small amount of dust in atmosphere has a negligible effect on the performance of PV module (Siddiqui and Bajpai 2012). Dust accumulation on PV module is dependent on the wind speed, $\mathrm{RH}$, tilt angle of module and dust type. In the Coal City, wind speed varies from 1.4 to $2.8 \mathrm{~m} / \mathrm{s}$ with an annual average of $2 \mathrm{~m} / \mathrm{s}$. Environmental parameter analysis of the Coal City shows that its humidity and wind speed both are in the moderate range so reduction in PV panel output due to dust is considered as $5.00 \%$. Amount of dust present in the ambiance of the concerned site will effect equally in all types of chosen PV technologies as tilt angle (tilted at latitude angle) and environmental condition are the same. Study of meteorological parameters is important because it provides data representative of Dhanbad's specific conditions; it can be used to make projections and for sizing of PV systems.

\section{Technology selection}

Technology selection plays an important role for new PV power project. In a laboratory scale, there are many new PV technologies available such as organic solar cell

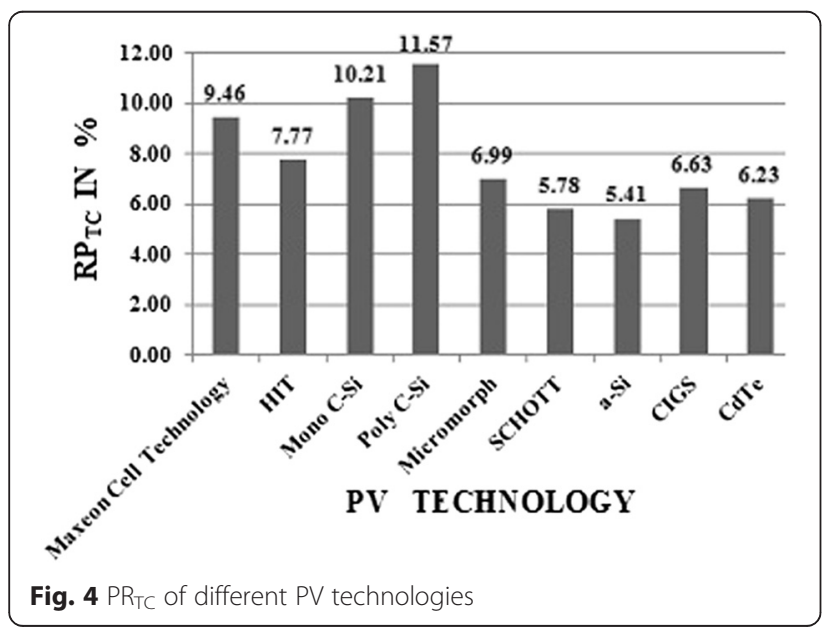

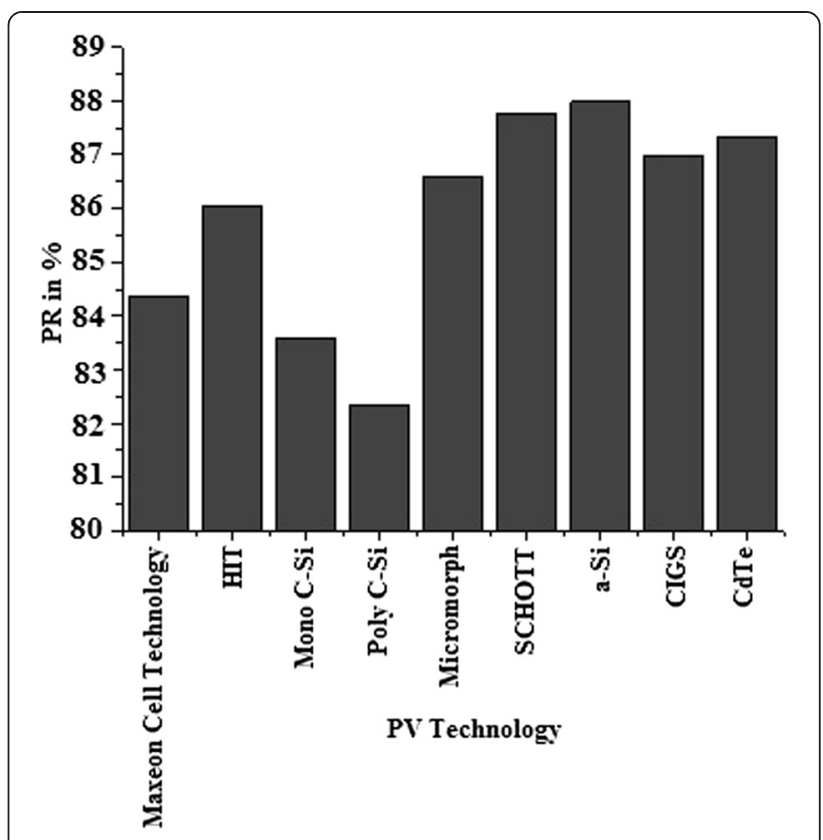

Fig. 5 PR for different PV technologies

and dye-sensitized solar cells, but they are not used commercially for PV power plant. Hence, nine commercial PV technologies from reputed manufacturers are considered which are extensively tested and widely used for commercial PV power plant projects. Required specifications of the selected PV technologies are enlisted in Table 1.

\section{Results and discussion}

Characterization of different PV panels under the environmental conditions of the Coal City

Comparisons of different parameters for nine different technologies are shown consecutively in this section.

Percentage decrement in power output due to temperature rise of PV power plants for different technologies is shown in Fig. 4. From Fig. 4, it is very clear

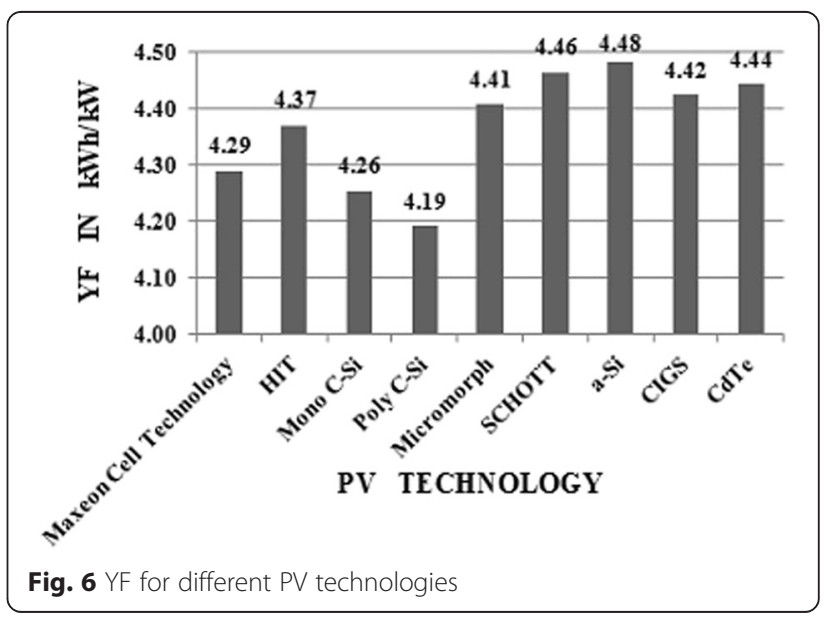


Table 2 Performance parameters of different PV technologies

\begin{tabular}{llll}
\hline Technology & $\mathrm{RP}_{\mathrm{TC}}$ & $\mathrm{PR}$ & $\mathrm{YF}$ \\
\hline Maxeon Cell Technology & 9.46 & 84.37 & 4.29 \\
HIT & 7.77 & 86.03 & 4.37 \\
Mono-crystalline & 10.21 & 83.57 & 4.26 \\
Poly-crystalline & 11.57 & 82.31 & 4.19 \\
Micromorph & 6.99 & 86.60 & 4.41 \\
SCHOTT & 5.78 & 87.76 & 4.46 \\
a-Si & 5.41 & 87.98 & 4.48 \\
CIGS & 6.63 & 86.98 & 4.42 \\
CdTe & 6.23 & 87.35 & 4.44 \\
\hline RP Is
\end{tabular}

$\mathrm{RP}_{\mathrm{TC}}$ is the reduction in power output due to temperature correction in $\%, \mathrm{PR}$ is the performance ratio in $\%$, andYF is the yield factor in $\mathrm{kWh} / \mathrm{kW} . \mathrm{DF}=5 \%$

that $\mathrm{PR}_{\mathrm{TC}}$ is minimum for a-Si technology with $5.41 \%$ and maximum for poly-crystalline silicon (Poly C-Si) technology with $11.57 \%$. $\mathrm{PR}_{\mathrm{TC}}$ for Maxeon Cell Technology, heterojunction with intrinsic thin layer (HIT), Mono C-Si, Poly C-Si, Micromorph, SCHOTT, CIGS and CdTe technologies are 21.78, 30.40, 47.02, 53.24, $22.66,6.43,18.43$ and $13.12 \%$, respectively, which is greater with respect to a-Si technology.

Performance ratios for nine different PV technologies are shown in Fig. 5. Highest PR of $87.98 \%$ is observed for a-Si technology as its reduction in power output due to temperature variation is minimum. PR of Poly C-Si technology is minimum with a value of $82.31 \%$. PR values of Maxeon Cell Technology, HIT, Mono C-Si, Poly C-Si technologies are 4.10, 2.21, 5.01 and 6.44 \%, respectively, which is lesser than a-Si technology. PR values of a-Si, SCHOTT, CIGS and CdTe technologies are very close to each other. Low PR of Poly C-Si technology is observed due to more effect of temperature variation on power output.

Energy yield factor (YF) for the nine different technologies are shown in Fig. 6. It is observed that YF is maximum for a-Si technology with a value of 4.48. Minimum YF value is seen for Poly C-Si technology due to the effect of temperature. YF values of Maxeon Cell Technology, HIT, Mono C-Si and Poly C-Si technologies are $4.29,2.50,5.08$ and $6.51 \%$, respectively, which is lesser than a-Si technology. The same is only 1.68, 0.39, 1.29 and $0.86 \%$ lesser compared to a-Si technology for Micromorph, SCHOTT, CIGS and CdTe technologies, respectively. A finding from this work is tabulated in Table 2.

From Table 2, it is observed that the effect of temperature on a-Si technology is minimum among the nine selected PV technologies, PR and YF are maximum for this technology due to lesser effect of temperature on this technology. For HIT technology, PR and YF are 1.97 and $1.87 \%$, respectively, which is more compared to Maxeon Cell Technology. It can be concluded that best suited technology for Dhanbad's environmental condition is a-Si from a technical performance point of view.

\section{Life cycle assessment}

Life cycle assessment of selected nine PV technologies is presented in this section. Capital cost, annual operation and maintenance cost, and salvage value for different types of PV technology-based PV power plants are collected from the PV plant developers. Table 3 shows the capital cost of selected nine different PV technologies. Capacity of the PV plant is considered $1 \mathrm{MW}$ for convenience.

Results show that capital cost is maximum for Maxeon Cell Technology, whereas minimum for a-Si technology followed by poly C-Si, SCHOTT, CdTe and CIGS technology-based PV plants.

Total outflow of money for different PV technologies are tabulated in Table 4. Maximum outflow of Rs.53.8227769 Crores is calculated for Maxeon Cell Technology and Rs.7.4808893 Crores is the outflow calculated for a-Si technology-based PV plant. Outflow for a-Si technology-based PV power plant is minimum among the selected nine PV technologies in this paper.

Table 3 Capital cost of 1-MW PV power plants based on different PV technologies

\begin{tabular}{|c|c|c|c|c|c|c|c|c|}
\hline Technology & $C_{\text {PVM }}$ (Crores) & $C_{L}$ (Crores) & $\mathrm{C}_{\mathrm{CG}}($ Crores $)$ & $C_{\text {MS }}$ (Crores) & C $C_{\text {PCu}}$ (Crores) & $C_{C T}$ (Crores) & $C_{p p}($ Crores $)$ & $\overline{C_{C}(\text { Crores })}$ \\
\hline Maxeon Cell Technology & 29.43946 & 2.198575 & 4.450774 & 4.450774 & 3.96816 & 4.879765 & 4.289903 & 53.67741 \\
\hline HIT & 7.3439 & 0.548452 & 1.11028 & 1.11028 & 0.989888 & 1.217295 & 1.070149 & 13.39024 \\
\hline Mono-crystalline & 6.386 & 0.476914 & 0.965461 & 0.965461 & 0.860772 & 1.058517 & 0.930565 & 11.64369 \\
\hline Poly-crystalline & 4.1509 & 0.309994 & 0.62755 & 0.62755 & 0.559502 & 0.688036 & 0.604867 & 7.568399 \\
\hline $\begin{array}{l}\text { Micromorph (Mono C-Si and } \\
\text { amorphous silicon hybrid) }\end{array}$ & 5.81126 & 0.433992 & 0.878569 & 0.878569 & 0.783303 & 0.963251 & 0.846814 & 10.59576 \\
\hline SCHOTT & 4.27862 & 0.319533 & 0.646859 & 0.646859 & 0.576717 & 0.709207 & 0.623478 & 7.801273 \\
\hline $\mathrm{a}-\mathrm{Si}$ & 4.02318 & 0.300456 & 0.60824 & 0.60824 & 0.542287 & 0.666866 & 0.586256 & 7.335525 \\
\hline CIGS & 5.36424 & 0.400608 & 0.810987 & 0.810987 & 0.723049 & 0.889155 & 0.781674 & 9.7807 \\
\hline CdTe & 4.66178 & 0.348148 & 0.704786 & 0.704786 & 0.628364 & 0.772718 & 0.679312 & 8.499894 \\
\hline
\end{tabular}


Table 4 Total outflow of money for different PV technology-based 1-MW power plants

\begin{tabular}{lll}
\hline Technology & NPV $_{\mathrm{OMC}}$ (Crores) & $\mathrm{TO}_{\mathrm{M}}$ (Crores) \\
\hline Maxeon Cell Technology & 0.1453644 & 53.8227769 \\
HIT & 0.1453644 & 13.5356083 \\
Mono-crystalline & 0.1453644 & 11.7890547 \\
Poly-crystalline & 0.1453644 & 7.7137631 \\
Micromorph (Mono C-Si and & 0.1453644 & 10.7411226 \\
amorphous silicon hybrid) & & \\
SCHOTT & 0.1453644 & 7.9466369 \\
a-Si & 0.1453644 & 7.4808893 \\
CIGS & 0.1453644 & 9.9260643 \\
CdTe & 0.1453644 & 8.6452583 \\
\hline
\end{tabular}

Net present value (NPV) and payback period (PBP) of nine different technology-based PV power plants are depicted in Table 5. Negative value of NPV indicates project is not viable and positive value indicates project is viable. NPV analysis concludes that Maxeon Cell Technology, HIT, Mono C-Si, Micromorph and CIGSbased PV power plants are not feasible for the environmental condition of Dhanbad. NPV study shows that economically best suitable PV technology is a-Si technology for the concerned site. Tariff of electricity generated from PV power plant is considered as Rs.4.00/kWh to make it compatible with electricity generated from coal-based thermal power plant. For the concerned site, 11.43 years is the PBP of a-Si-based 1-MW PV power plant. PBPs of all other technology-based PV power plants are below 25 years except Maxeon Cell Technology.

\section{The global warming impacts of different photovoltaic technologies}

Electricity generated from solar PV is free from toxic pollutant and global warming emissions. Though no global warming emissions are associated with the generation of electricity from solar energy, there are emissions associated with other stages of the solar life cycle, such as manufacturing process, materials transportation, installation, maintenance, decommissioning and dismantlement. Value of this emission varies from technology to technology. Global warming is caused by the emission of green house gases (GHG). GHG comprises of oxides of carbon $\left(\mathrm{CO}_{2}, \mathrm{CO}\right)$, sulphur $\left(\mathrm{SO}_{2}\right)$ and nitrogen (NO), etc. Calculated GHG emission reduction for nine different PV technology-based plants due to the replacement of coal-based electricity is shown in Table 6 and Fig. 7, respectively.

Maximum $\mathrm{AER}_{\mathrm{GHG}}$ is observed for a-Si PV technology with a value of 1644.34 tonnes and minimum AER $_{\text {GHG }}$ of 1537.28 tonnes is found for poly C-Si technology in the concerned site.

From the global warming impact study, it is seen that a-Si is again the best suitable technology for the Coal City-Dhanbad.

\section{Conclusion}

The study concludes that a-Si is the best fitted PV technology technically, economically and from a global warming impact point of view under the environmental condition of the Coal City of India. Findings of the study are presented below.

- For amorphous silicon solar cells, $\mathrm{RP}_{\mathrm{TC}}$ is $5.41 \%$ with respect to the reference value at $25^{\circ} \mathrm{C}$.

- Among the nine PV technologies, maximum PR is observed for a-Si technology with a value of $87.98 \%$.

- It is observed that YF is maximum for a-Si technology with a value of 4.48 .

- Amorphous silicon is the best suitable PV technology for the Coal City from a technical performance point of view.

- NPV is maximum and PBP period is minimum for a 1-MW a-Si-based PV power plant with a value

Table 5 NPV and PBP of nine different technology-based 1-MW PV power plants

\begin{tabular}{|c|c|c|c|c|c|c|c|}
\hline Technology & $\mathrm{AS}_{\mathrm{EG}}$ (Crores) & NPV $V_{\text {SEG }}$ (Crores) & $\begin{array}{l}\text { SV (Crores) } \\
10 \% \text { of CC }\end{array}$ & NPV $V_{S V}$ (Crores) & $\mathrm{Tl}_{\mathrm{M}}$ (Crores) & NPV (Crores) & PBP (years) \\
\hline Maxeon Cell Technology & 0.6263992 & 9.4567102 & 5.3677412 & 0.4954210 & 9.9521312 & -43.8706457 & 85.92408 \\
\hline HIT & 0.6381056 & 9.6334399 & 1.3390244 & 0.1235866 & 9.7570265 & -3.7785818 & 21.21218 \\
\hline Mono-crystalline & 0.6212310 & 9.3786859 & 1.1643690 & 0.1074666 & 9.4861525 & -2.3029022 & 18.97693 \\
\hline Poly-crystalline & 0.6118355 & 9.2368425 & 0.7568399 & 0.06985329 & 9.3066958 & 1.59293272 & 12.60758 \\
\hline $\begin{array}{l}\text { Micromorph (Mono C-Si and } \\
\text { amorphous silicon hybrid) }\end{array}$ & 0.6434813 & 9.7145976 & 0.10595758 & 0.09779461 & 9.8123923 & -0.92873034 & 16.69221 \\
\hline SCHOTT & 0.6518736 & 9.8412957 & 0.7801273 & 0.07200262 & 9.9132983 & 1.96666142 & 12.19046 \\
\hline $\mathrm{a}-\mathrm{Si}$ & 0.6544457 & 9.8801261 & 0.7335525 & 0.06770396 & 9.9478301 & 2.46694077 & 11.43088 \\
\hline CIGS & 0.6459928 & 9.7525131 & 0.9780700 & 0.09027195 & 9.8427850 & -0.083279265 & 15.3656 \\
\hline CdTe & 0.6487948 & 9.7948154 & 0.8499894 & 0.07845062 & 9.8732660 & 1.22800767 & 13.3251 \\
\hline
\end{tabular}

$d=10 \% /$ annum, $g=5.6 \%$ /annum, $n=25$ years, $\mathrm{IC}_{\mathrm{P}}=1 \mathrm{MW}, \mathrm{T}_{\mathrm{E}}=\neq 4.00$, and $i=6 \% /$ annum 
Table 6 The global warming impacts of different PV technologies

\begin{tabular}{|c|c|c|c|c|c|}
\hline Technology & Annual CO2 saving (kg) & Annual CO saving (kg) & Annual SO2 saving (kg) & Annual NO saving (kg) & $\mathrm{AER}_{\mathrm{GHG}}$ (tonnes) \\
\hline Maxeon Cell Technology & $1,550,338$ & 6231.106 & $13,545.88337$ & 3758.395 & 1573.873 \\
\hline HIT & $1,579,311$ & 6347.555 & $13,799.0327$ & 3828.633 & 1603.286 \\
\hline Mono-crystalline & $1,537,547$ & 6179.695 & $13,434.12063$ & 3727.386 & 1560.888 \\
\hline Poly-crystalline & $1,514,293$ & 6086.234 & $13,230.94285$ & 3671.013 & 1537.281 \\
\hline $\begin{array}{l}\text { Micromorph (Mono C-Si and } \\
\text { amorphous silicon hybrid) }\end{array}$ & $1,592,616$ & 6401.031 & $13,915.2839$ & 3860.888 & 1616.794 \\
\hline SCHOTT & $1,613,387$ & 6484.513 & $14,096.76744$ & 3911.242 & 1637.88 \\
\hline $\mathrm{a}-\mathrm{Si}$ & $1,619,753$ & 6510.099 & $14,152.38848$ & 3926.674 & 1644.342 \\
\hline $\mathrm{CIGS}$ & $1,598,832$ & 6426.013 & $13,969.59431$ & 3875.957 & 1623.104 \\
\hline CdTe & $1,605,767$ & 6453.887 & $14,030.18857$ & 3892.769 & 1630.144 \\
\hline
\end{tabular}

of Rs.2.46694077 Crores and 11.43 years, respectively. So it is economically the best fitted PV technology for the concerned site.

- Per annum, 1644.34 tonnes of GHG emission will be reduced from a 1-MW a-Si-based PV plant due to the saving of thousand tonnes of coal used nowadays to produce electricity.

Different solar PV power plants available in India can be used to verify the study. But in the Coal City of India, no PV plant is still installed. So comparison of the study result with practical PV power plant data is not possible for the concerned site. Though the ministry has future plans for installation of PV power plant in Dhanbad, this paper will help the PV project developers, planning commission and engineers to choose the best suitable PV technology for the Coal City-Dhanbad, not only considering the technical performance but also from the economic and environmental point of view.

\section{Nomenclature}

STC, standard test conditions

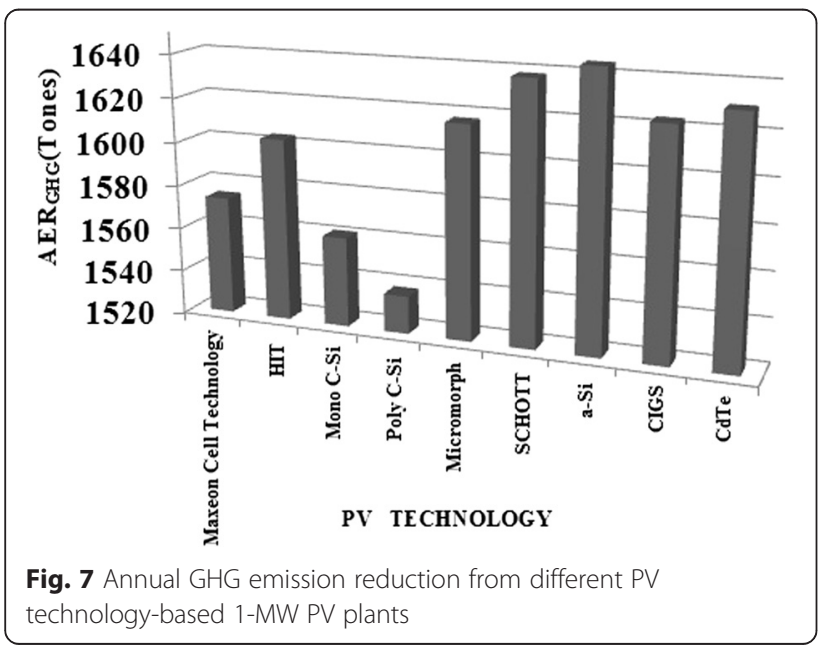

NASA, National Aeronautics and Space Administration NOCT, nominal operating cell temperature

DF, dust factor (\%)

$\mathrm{PR}$, performance ratio (\%)

YF, yield factor

$\mathrm{M}$, manufacturer

MT, module type

HIT, heterojunction with intrinsic thin layer

Mono C-Si, mono-crystalline silicon

Poly C-Si, poly-crystalline silicon

a-Si, amorphous silicon

CdTe, cadmium telluride

CIGS, copper indium gallium selenide

NTPC, National Thermal Power Corporation

NVVN, NTPC Vidyut Vyapar Nigam Ltd

LCA, life cycle assessment

GHG, green house gas

$T_{\text {PO }}$, panel operating temperature $\left({ }^{\circ} \mathrm{C}\right)$

$T_{\mathrm{AMB}}$, ambient temperature $\left({ }^{\circ} \mathrm{C}\right)$

$G$, irradiance $\left(\mathrm{W} / \mathrm{m}^{2}\right)$

$\mathrm{RP}_{\mathrm{TC}}$, reduction in power output due to temperature correction (\%)

$\gamma$, temperature coefficient of power for PV panel $\left(\% /{ }^{\circ} \mathrm{C}\right)$

$T_{\text {STC }}$, temperature of the PV module at STC (i.e. $25^{\circ} \mathrm{C}$ )

$P_{\text {TC }}$, panel output after temperature correction

$P_{\text {MAX }}$, power output at STC

$h_{\text {EFSLAT, }}$ equivalent full sunshine hours in latitude angle tilted surface $(\mathrm{h})$

$I_{\mathrm{T}}$, insolation on tilted surface, for Dhanbad, fixed tilt is taken as $23^{\circ}\left(\mathrm{kWh} / \mathrm{m}^{2} /\right.$ day $)$

$\xi_{\text {Panel }}$, energy output from PV panel

$\mathrm{Inv}_{\mathrm{O} / \mathrm{P}}$ energy output from inverter

$\eta_{\text {inv }}$, inverter efficiency (\%)

$A_{\mathrm{a}}$, active area of panel $\left(\mathrm{m}^{2}\right)$

$\eta_{\text {Panel }}$, solar panel efficiency (\%)

Tech, technology

$\mathrm{T}_{\mathrm{C}}$, temperature coefficient $\left(\% /{ }^{\circ} \mathrm{C}\right)$

$\mathrm{W}_{\mathrm{p}}$, Watt peak

$C_{\mathrm{C}}$, capital cost of PV plant 
$C_{\mathrm{PVM}}$, cost of PV module

$C_{\mathrm{L}}$, land cost

$C_{\mathrm{CG}}$, cost of civil and general works

$C_{\mathrm{MS}}$, cost of mounting structures

$C_{\mathrm{PCU}}$, cost of power conditioning unit

$C_{\mathrm{CT}}$, evacuation cost up to inter-connection point

(cables and transformer)

$C_{\mathrm{PP}}$, preliminary and pre-operative expenses

$\mathrm{NPV}_{\mathrm{OMC}}$, net present value of operation and mainten-

ance cost

$C_{\mathrm{AOM}}$, annual operation and maintenance cost

$d$, discount rate (\%)

$g$, escalation in operation and maintenance cost (\%)

$n$, lifetime of the project (years)

$\mathrm{TO}_{\mathrm{M}}$, total outflow of money

$\mathrm{AS}_{\mathrm{EG}}$, annual saving from electricity generated from the PV plant

$\mathrm{IC}_{\mathrm{B}}$, installed capacity of PV plant

YF, yield factor

$N$, number of working days in the year

$T_{\mathrm{E}}$, tariff of electricity

$\mathrm{NPV}_{\mathrm{SEG}}$, net present value of lifetime saving from elec-

tricity generated by the PV plant

$g$, inflation rate of electricity tariff (\%)

$\mathrm{TI}_{\mathrm{M}}$, total inflow of money

$\mathrm{NPV}_{\mathrm{SV}}$, net present value of salvage value

$\mathrm{SV}$, salvage value

$\mathrm{NPV}_{\mathrm{B}}$ net present value of PV power plant

PBP, payback period in years

$\mathrm{AER}_{\mathrm{GHG}}$, annual GHG emission reduction from PV power plant

$\mathrm{ECP}_{\mathrm{GHG}}$, GHG emission from coal-based power plant/ $\mathrm{kWh}$

\section{Competing interests}

The authors declare that they have no competing interests.

\section{Authors' contributions}

SC carried out the mathematical equations required for technical mapping, climatic characteristics for the Coal City of India, technology selection, characterization of different PV panels under the environmental conditions of the Coal City, participated in the sequence alignment and drafted the manuscript. PKS conceived of the study and participated in its design and coordination and helped to draft the manuscript. Both authors read and approved the final manuscript.

\section{Authors' information}

SC was born in Galsi, India. She received her B. Tech in Electrical Engineering from WBUT, India, in 2011 and M. Tech from Tezpur Central University, India, in Energy Technology in 2013. Now she is pursuing Ph.D. from Electrical Engineering Department of Indian School of Mines, Dhanbad, India. Her area of specialization is Solar Photovoltaic Power generation.

PKS received his Bachelor, Post-Graduate and Ph.D. (Engineering) degrees in 1997, 1999 and 2002 respectively in Electrical Engg. from Jadavpur University, West Bengal, India. Currently, he is working as Professor and Head in Electrical Engineering Department of Indian School of Mines, Dhanbad, India. He has total experience of 18 years in teaching and industry. He has four Patents. He has several journal and conference publications in national and international level. He is principal investigator of few Govt. funded projects. He has guided a large number of doctoral candidates and M. Tech students. His current areas of interest are power electronics applications, application of high frequency converter, energy-efficient devices, energy-efficient drives, computer-aided power system analysis, condition monitoring and lighting and communication systems for underground coal mines.

\section{Acknowledgements}

Authors would like to thank NASA renewable energy resource website team, manufactures of PV modules, PV plant developers and the Ministry of New and Renewable Energy for their valuable freeware data.

Received: 30 December 2014 Accepted: 18 June 2015

Published online: 28 July 2015

\section{References}

Adiyabat, A, Kurokawa, K, Otani, K, Enebish, N, Batsukh, G, Battushig, M, Ochirvaani, D, \& Ganbat, B. (2006). Evaluation of solar energy potential and PV module performance in the Gobi Desert of Mongolia. Progress in Photovoltaics: Research and Applications, 14(6), 553-566.

Chen, HH, Kang, H, \& Lee, AHI. (2010). Strategic selection of suitable projects for hybrid solar-wind power generation systems. Renewable and Sustainable Energy Reviews, 14, 413-421.

Cher Ming Tan, Boon Khai Eric Chen and Kok Peng Toh. (2010). Humidity study of a-Si PV cell. Microelectronics Reliability, 50, 1871-1874.

Daghigh, R, Ibrahim, A, Jin, GL, Ruslan, MH, \& Sopian, K. (2011). Predicting the performance of amorphous and crystalline silicon based photovoltaic solar thermal collectors. Energy Conversion and Management, 52, 1741-1747.

Fiorenza, G, Sharma, VK, \& Braccio, G. (2006). Techno-economic evaluation of a salt gradient solar pond: a potential energy source for seawater desalination and power generation. International Energy Journal, 7(1), 43-56.

Garcia, A, \& Balenzategui, J. (2004). Estimation of photovoltaic module yearly temperature and performance based on nominal operation cell temperature calculations. Renewable Energy, 29(12), 1997-2010.

Garg, HP. (1974). Effect of dirt on transparent covers in flat plate solar energy collectors. Solar Energy, 15(4), 299-302.

Gwandu, BAL, \& Creasey, DJ. (1995). Humidity: a factor in the appropriate positioning of a photovoltaic power station. Renewable Energy, 6(3), 313-316.

NTPC Vidyut Vyapar Nigam Limited. http://nvvn.co.in/(Accessed May 2015)

Grid connected Solar Systems. http://www.mnre.gov.in/solar-mission/jnnsm/ introduction-2/ (Accessed May 2015)

Solar Energy Case Studies: Reduce Electricity Bills with Solar Power http://www.relyonsolar.com/(Accessed May 2015)

Google Map. https://maps.google.co.in. (Accessed July 2014)

Kempe, MD. (2006). Modeling of rates of moisture ingress into photovoltaic modules. Solar Energy Materials \& Solar Cells, 90(16), 2720-2738.

Makrides, G, Zinsser, B, Georghiou, GE, Schubert, M, \& Werner, JH. (2010). Evaluation of grid-connected photovoltaic system performance losses in Cyprus. In Proceedings of the 7th Mediterranean Conference and Exhibition on Power Generation, Transmission, Distribution and Energy Conversion, Agia Napa, Cyprus. 7-10 November.

Malik, A, \& Damit, SJBH. (2003). Outdoor testing of single crystal silicon solar cells. Renewable Energy, 28(9), 1433-1445.

Mani, M, \& Pillai, R. (2010). Impact of dust on solar photovoltaic (PV) performance: Research status, challenges and recommendations. Renewable and Sustainable Energy Reviews, 14, 3124-3131.

Mousazadeh, H, Keyhani, A, Javadi, A, Mobli, H, Abrinia, K, \& Sharifi, A. (2009). A review of principle and sun-tracking methods for maximizing solar systems output. Renewable and Sustainable Energy Reviews, 13(8), 1800-1818.

Muneer, T, Asif, M, \& Munawwar, S. (2005). Sustainable production of solar electricity with particular reference to the Indian economy. Renewable and Sustainable Energy Reviews, 9(5), 444-473.

Nanda, RT, \& Raturi, A. (2013). Feasibility study of a grid connected photovoltaic system for the central region of Fiji. Applied Solar Energy, 49(2), 110-115.

Pavlovic, TM, Milosavljevic, DD, Mirjanic, D, Pantic, LS, Radonjic, IS, \& Pirsl, D. (2013). Assessments and perspectives of PV solar power engineering in the Republic of Srpska (Bosnia and Herzegovina). Renewable and Sustainable Energy Reviews, 18, 119-133.

Ross, RG. (1976). Interface design considerations for terrestrial solar cell modules. In Proceedings of the 12th IEEE Photovoltaic Specialist's Conference, Baton Rouge, LA. 15-18November.

Santana-Rodŕiguez, G, Vigil-Galan, O, Jimenez-Olarte, D, Contreras-Puente, G, Monroy, BM, \& Escamilla-Esquivel, A. (2013). Evaluation of a grid-connected photovoltaic system and in-situ characterization of photovoltaic modules 
under the environmental conditions of Mexico City. Revista Mexicana de Fisica, 59(2), 88-94.

Siddiqui, R, \& Bajpai, U. (2012). Correlation between thicknesses of dust collected on photovoltaic module and difference in efficiencies in composite climate. International Journal of Energy and Environmental Engineering, 3(26), 1-7.

Skoplaki, E, \& Palyvos, JA. (2009). Operating temperature of photovoltaic modules: a survey of pertinent correlations. Renewable Energy, 34, 23-29.

Surface meteorology and solar energy. NASA renewable energy resource website. https://eosweb.larc.nasa.gov/sse/. (Accessed July 2014)

Swift, KD. (2013). A comparison of the cost and financial returns for solar photovoltaic systems installed by businesses in different locations across the United States. Renewable Energy, 57, 137-143.

Submit your manuscript to a SpringerOpen ${ }^{\circ}$ journal and benefit from:

- Convenient online submission

- Rigorous peer review

- Immediate publication on acceptance

- Open access: articles freely available online

- High visibility within the field

- Retaining the copyright to your article

Submit your next manuscript at $>$ springeropen.com 